Aure, B., Lædre, O., and Lohne, J. 2020. "Experiences from Allowing Maximum Two Contract Tiers in the Vertical Supply Chain." In: Tommelein, I.D. and Daniel, E. (eds.). Proc. $28^{\text {th }}$ Annual Conference of the International Group for Lean Construction (IGLC28), Berkeley, California, USA, doi.org/10.24928/2020/0123, online at iglc.net.

\title{
EXPERIENCES FROM ALLOWING MAXIMUM TWO CONTRACT TIERS IN THE VERTICAL SUPPLY CHAIN
}

\author{
Beate Aure $^{1}$, Ola Ladre ${ }^{2}$, and Jardar Lohne ${ }^{3}$
}

\begin{abstract}
The AEC-industry is negatively affected by criminal actors seeking economic profit. In order to combat crime, Norwegian authorities have introduced action plans and strategies. This study concentrates on experiences Norwegian contractors have had with a requirement of maximum two contract tiers in their vertical supply chain. Six semistructured interviews with project managers and advisors from contractors in Norway have been conducted, in addition to a literature study. The findings show that the contractors have close to never experienced challenges with the requirement of maximum two contract tiers. The only challenge in this matter is when their sub-sub-contractor needs specialist competence or specialist equipment and are not allowed to use another contract tier. By discussing why the requirement of maximum two contract tiers seemingly works, how it is organized and what perceptions that have been made, this study are among the first to document the conctractors' experiences from allowing maximum two contract tiers.
\end{abstract}

\section{KEYWORDS}

AEC-industry, contract tiers, work related crime, supply chain

\section{INTRODUCTION}

Several analysis reports, official agencies reports and industry initiated reports have indicated that earlier measures taken have not prevented an escalation of criminal activities over the last two decades in the Norwegian AEC-industry (Lohne et al. 2019a; Wold et al. 2019). Construction projects have peculiar characteristics, as for example site production, unique product, temporary organization (Ballard and Howell 1998), rendering them vulnerable for work related crime. Extensive research has been carried out over the last five years in the Norwegian context to understand criminal activity in the AEC industry in light of these inherent characteristics. Examples of this can be found in Kjesbu et al. (2017) on the subject of false steel qualities, Engebø et al. (2016) on the

1 MSc Student, Department of Civil and Environmental Engineering, NTNU - Norwegian University of Science and Technology, Trondheim, Norway, +47476 76 796, beate-aure@,hotmail.com, orcid.org/0000-0002-0241-9230

2 Professor, Department of Civil and Environmental Engineering, NTNU - Norwegian University of Science and Technology, Trondheim, Norway, +4791189 938, ola.ladre@ntnu.no, orcid.org/00000003-4604-8299

3 Researcher, Dr. Art., Department of Civil and Environmental Engineering, NTNU - Norwegian University of Science and Technology, Trondheim, Norway, +47 93444 930, jardar.lohne@,ntnu.no, orcid.org/0000-0002-2135-3468 
existence of false materials, Wold et al. (2019) on investigating processing of building permits in Norwegian municipalities; Evjen et al. (2019) on subcontractor perspectives on crime; Lohne et al. (2020) on challenges concerning handover in AEC-projects; Svalestuen et al. (2015) on design phase challenges; etc.

The Norwegian Government presented in January 2015 a strategy to combat work related crime that resulted in a national coordination group and a joint action plan. In light of this, a common understanding of the problem emerged and new working methods where developed (Neby et al. 2016)

Among other measures, the Government strategy resulted in a requirement that restricts the number of contract tiers in construction projects. The main contractor can have sub-contractors and sub-sub-contractors, but is not allowed to have sub-sub-subcontractors. The main contractor can thus have maximum two contract tiers in the vertical supply chain (Brandi et al. 2017; Oslo Municipality n.d.) This is a response to the insight that when the supply chain becomes complex, problems and challenges will follow (Souza and Koskela 2014). Fulfilling of sufficient wages and working conditions, taxes and fees to the authorities and the main contractor's contract terms are inherently difficult to monitor. A long supply chain renders it difficult to verify that suppliers fulfil their obligations to workers and public authorities (Johansen and Steen 2017).

The requirement of maximum two contract tiers is mandatory in public construction projects carried out by the Norwegian Public Roads Administration (Haugen et al. 2017). Other public clients, such as Oslo and Skien municipalities, have similar requirements (Oslo Municipality, n.d.).

The available research is mainly related to communication between main contractors and their sub-contractors. It therefore does not examine the challenges a main contractor can face with not having enough contract tiers in the supply chain (Karim et al. 2006; Haelterman 2009). Most supply chain management research concentrate on the operational stage as the research indicate that this is where criminals exploit the lack of knowledge to make a profit (Souza and Koskela 2013). The research does equally not seem to be occupied with the perspective of the client, main contractors or sub-contractors. Experience show that the more links in the vertical supply chain, the more it is difficult for the client to avoid working crime (Brandi et al. 2017). Employees not receiving minimum wages, use of overtime beyond legal limits and other social dumping, lack of tax payment, use of illegal labour and bribes are still common for some companies in the Norwegian AEC-industry (Brandi et al. 2017). The maximum two contract tiers requirement intends to prevent this work related crime in the construction industry, but little research has been done on whether these measures works and on what the consequences are for the contractors. Therefore, this study examines the experiences of various main contractors addressing the following research questions:

- How do contractors satisfy the requirement of maximum two contract tiers?

- What challenges entail the requirement of maximum two contract tiers for the contractors?

\section{METHODOLOGY}

The research was conducted using a scoping literature review and six semi-structured interviews. The most important task of the scoping literature review is to generate the theoretical basis of the study, and it is estimated whether the study will contribute new knowledge (Mays et al. 2001).The literature review was initially linked to the work 
related crime in the construction industry, but later conducted according to the principles of Arksey and O'Malley (2005), based on the research questions. The steps were: (1) identified research questions; (2) identify relevant literature; (3) Selection of literature; (4) Survey of literature; (5) Summarize and report the results. The literature searches were limited to reputable databases such as Scopus, Web of Science, American Society of Civil Engineers (ASCE) and Google Scholar. In order to identify relevant literature from these databases the recommendations of Blumberg, et al. (2011) were followed. A filtration technique was applied to sort out unrelated literature and thus make the search more efficient. The literature was first filtrated by the title and keywords. If these indicated relevance, summaries and bibliography would be further read and examined. These often indicate whether the literature is relevant or not (Blumberg et al. 2011). Finally, the content of every literature source was evaluated according to credibility, objectivity, accuracy and suitability.

The main source of information and results were obtained from six interviews with project managers and different advisors in main contractors firms and an advisor from a Norwegian public client. In total the interviewees came from three different companies.

Interviewing is a qualitative technique and its purpose is to generate knowledge of the topic by looking at it as a whole, going in depth and increasing understanding (Tjora 2017). Also, interviews are exchange of experience where the interviewees should be able to encourage their own opinions and views (Dalen 2011).

The interviews were held in November 2019 where the interviewees were selected based on their knowledge about the requirement, their position e.g. safety, health and working environment advisors, project managers and advisors in the field of seriousness follow-up in addition to their experiences with work related crime on construction sites. By including both advisors and project managers the results could reflect the experiences of those at the construction site and those at the headquarters of the company.

The interviews were semi-structured. As recommended by Dalen (2011) the interview guide was constructed in such a way that the first questions were about the topic of work related crime in construction and then addressed the questions of most central part of the study, the research questions and requirement of maximum two contract tiers. It was designed two different interview guides where one was constructed for the main contractors and the other one for the client. This was mainly done because of the different aspect those two sides could generate. The interviews carried out face-to-face and lasted between 60 minutes to 90 minutes. Each interview was recorded, transcribed and approved by the interviewees.

\section{THEORETICAL BACKGROUND}

\section{IMPLEMENTED MEASURES}

Projects set standard contract terms for the procurement of goods, services and buildings. The Oslo model, the Skien model and the Telemark model are examples of these, which are all used in their respective municipalities and counties. The models are used on public construction projects and set standard requirements and contract terms for contractors who carry out projects for them (Fellesforbundet 2014).

These models were created in 2014/2015 and are now actively in use. The models have very similar features in which requirements and contract terms are set, with a few exceptions. Some of the common requirements in the models are set to percentage of skilled craftsmen and apprentices, internal control, HSE-card and electronic crew follow- 
up, insight into the supplier's relationship, wages and working conditions, payment to bank, and a ban on cash payment (Fellesforbundet 2014; Oslo Municipality, n.d.).

One of the requirements set in these models is the requirement that the main contractor only can use two contract tiers in their vertical supply chain. The Oslo model wants to further set the requirement to maximum one contract tier (Oslo Municipality, n.d.), and the opinions from the main contractors on this subject is also included in this study.

It is considered that the main contractor can have more impact on the administration, performance and quality on the work of their suppliers (Broft and Koskela 2018). Experiences indicate that with the higher number of tiers in the hierarchy comes a profit potential that criminals have by posting fictitious invoices. Because of this the rationale for implementing the requirement of maximum two contract tiers arose (Neby et al. 2016). fictitious invoices legitimize unlawful deductions for costs and Value-Added Tax (VAT), while at the same time avoiding taxes and fees released for other criminal purposes. The fraud involves inserting several sub-contractors in the vertical chain, by creating fictitious businesses where the sole task is to produce invoices that form the basis for deductions in the accounts of the companies higher up the chain (Neby et al. 2016). This is illustrated on figure 1 inspired by a figure in Neby et al. (2016).

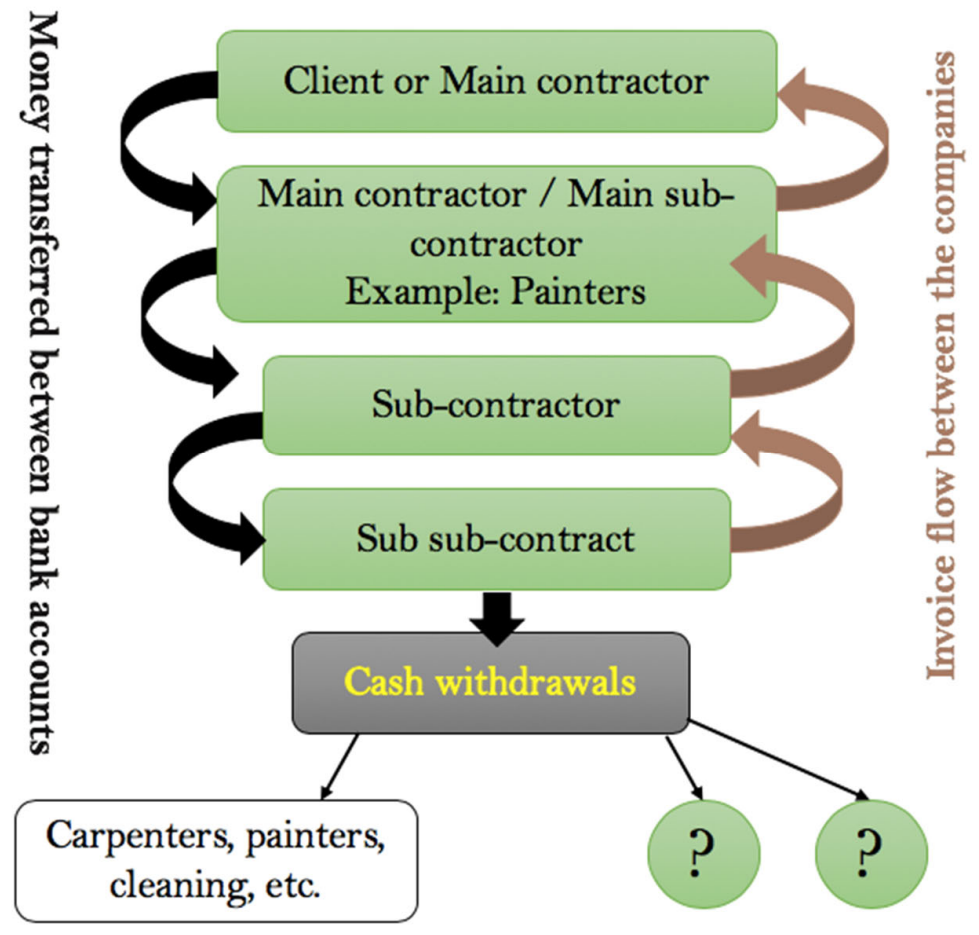

Figure 1: Patterns of action for criminals in the supply chain (Neby et al. 2016)

The figure displays how the invoice flow goes up the vertical chain and the money between the client, main contractor and sub-contractors is transferred down the chain. At some point in the vertical supply chain the money flow from bank accounts becomes untraceable when cash withdrawals is used. How this money is partitioned out is difficult to know and control for the client and main contractor. Who starts the criminal acts is difficult to know, it can be work related crime that main contractors are aware of and 
benefits from or it can be work related crime starting with the sub-sub contractors (Neby et al. 2016).

\section{Consequences of Work Related Crime}

Work related crime reveals incidents of multi-crime with offenses made, among other things, in pay and working conditions, social security, taxes and fees, camouflage of criminal acts in legal activities, the use of incorrect documentation, corruption, money laundering, currency smuggling and human trafficking (Skovly et al. 2017).

The consequences of work related crime can be considered as a major reason why prevention is taking place. In recent years there has been widespread development in the work related crime, the consequences of which include: lapse of the right to permanent employment with predictable wages to live off, lower productivity and quality in the industries / supply, poorer wages and working conditions for workers, fewer apprentices and serious failure in necessary recruitment to the construction industry (Gulliksen et al. 2014).

The standard of the working environment takes a step back when employees are exploited. For the society this reduces public revenues and increases expenditures that contribute to deficits when the law-abiding labour market has an adverse competitive effect by providing the criminal actors with a competitive advantage and outperforms (Gulliksen et al. 2014).

It is argued by Leff (1964) as referenced in Locatelli et. al (2016) that corruption can have a positive impact on economic growth. Corruption is a form of crime that comes under criminal law and the international bribery index ranks public construction contracts and construction among the top 20 in 2011 (Hardoon and Heinrich 2011). Leff (1964) was one of the first authors to support the effective corruption theory. His reasons for corruption assisting economic growth were, among other things, that the bureaucracies are motivated by bribes and thus they work harder, it helps attract foreign direct investment, it can introduce competitive elements for closed markets and introduces competitive bidding (Locatelli et al. 2016).

The control authorities have incentives with the problems and consequences of work related crime from an internal organizational perspective. More simply put, the need for the police force will increase with increasing criminal activity (Lohne, et al. 2019b). It is stated in Lohne et.al (2019b) that the focus of control authorities should be directed more towards the actors "at the top" of the supply chain, especially owners and main contractor, due to their large benefits from criminal activities (especially concerning reduced capital expenditure).

\section{Previous Work}

Previous work associated with the experiences of the implemented measures from the main contractors is relatively limited. Nevertheless, within the Norwegian context, Stormo (2017) has investigated the effects that the introduction of two contract tiers in the vertical supply chain has had on follow-up, control and safety in the projects of the Norwegian Public Roads Administration. In the Thesis, Stormo (2017) concludes that the measure has had a positive effect on the follow-up, control and safety of the subcontractors where the measure was implemented. It is also pointed out that it is uncertain whether the effects are isolated from the introduction of two contract tiers, or whether other implemented measures have contributed to positive effects. 
The master's thesis has also considered the measure of reducing contract tiers from two to one. Supporters of this requirement believe that several contract tiers, including two, results in messages not being communicated and that the lowest activities in the hierarchy feel they don't have ownership of the project. They are too far away from where the decisions are made in addition to that control and follow-up is difficult for the main contractor. However, it is concluded that it is not recommended to reduce the numbers of contract tiers even more because it benefits the developer in regards to control, and does not take into account other people involved in the project (Stormo 2017).

Other findings made in connection with work related crime are that interdisciplinary cooperation is important for the prevention of crime (Neby et al. 2016). This can be information sharing about actors and problems, joint work processes between the agencies involved, new established meeting places, increased understanding and knowledge of the problems as well as better coordination through the use of sanctions and measures. From the surveys on how intergovernmental state cooperation works, it is clear that at both a strategic and operational level, this type of measures and intergovernmental cooperation will reduce the extent of work related crime and provide a basis for a positive benefit for the resource effort (Neby et al. 2016). This also applies to information where the practical aspects of it and communication are particularly challenging for cooperation in the prevention of work related crime. It is reasoned that greater emphasis should be placed on sharing information through the establishment of controlled systems and platforms, and that existing barriers should be broken down. Socalled "meta-information" that deals with work methods, routines, contact information, etc. is also very important for many actors and is information that should be shared (Neby et al. 2016).

\section{RESULTS AND DISCUSSION}

\section{The Requirement of MaX. Two Contract TIERS}

The Oslo model lists seriousness requirements which are implemented in public construction projects with Oslo municipality as the client. Their requirements have similarities to the model and range from management system requirements, quality assurance and risk management, HSE, pay and working conditions, professional craftsmen and apprentices and the numbers of contract tiers. It appears that several of the measures in the Oslo model are implemented to the contractors own seriousness requirements.

The idea behind requiring maximum two contract tiers was because of suspicions that the last business in the vertical supply chain impossibly could gain any profit as it was too many sub-contractors above that had taken their share of the profit. For example, as stated in an interview, there could be circumstances where a sub-contractor had none of his own employees present on a project, but the job was passed on to someone else. It could also occur that the main contractor himself wasn't informed that there were two or three sub-sub-contractors under various sub-contractors. Eventually this showed that it was a lack of control in what the last business in the vertical chain would make. This was considered insufficient and it was agreed that a system for a better control had to be implemented.

There has been a diminishing control consistently with the increasing of contract tiers in the supply chain. The organization of the measure was intended to create better control and follow-up opportunities for the main contractors in addition to criminal businesses 
would have more difficulty in deducting taxes and obtaining profits with fictitious invoices (Neby et al. 2016). There is reason to believe that the problem considering fictitious invoices has decreased as the criminal businesses no longer have the opportunity to hide criminal acts far down the vertical chain.

The control and follow-up are more complicated. The main contractors are mainly responsible for checking up on the sub-contractors. Nevertheless, it is of interest to the client to follow up on which sub-contractors are being used. Some literature indicates that the reduction of contract tiers in the vertical chain has had a positive effect on the main contractors' follow-up (Stormo 2017). The results in this study show somewhat otherwise. It is apparent that the contract tiers has not changed the effort to follow up, but the different is that they are now directly under the main contractors and is indicating that it is still demanding a lot of work with follow-ups. The main contractors still experience some challenges associated with following up the sub-sub-contractor, such as to followup that they obey and comply with the requirements set by the main contractor. It is argued that the main contractors wouldn't have any control over the third of fourth subcontractor in a vertical chain before, but this doesn't mean that the upper sub-contractors are better followed up now that the requirement is implemented. But because of the now closer and more directly contractual relationship between main contractor and subcontractors it should be easier for the main contractor to follow up due to access, transparency and connection.

Today, the follow-ups are mainly happening in a Norwegian computer program called "HMSREG" translated to HSE-Registration. This program is relatively new and is mainly used by the biggest contractors. In the program it is possible for both the client and main contractor to discover the deviations of the sub-contractors early as they upload documentation and the system detects deviations immediately. HMSREG is considered the most important tool and help device that is used in the Norwegian AEC-industry today. It was developed with inspiration from the Oslo model and is based on information including control questions, auditors note, $b$-rating, debt negotiation confirmation or tax certificate. Based on this the contractors can choose which provisions to implement in their program. Before the main contractors had to check every sub-contractors bank status update separately, but with HMSREG the contractors can easily see every sub-contractor and sub-sub-contractor on their project in addition to their status. The program shows a green, yellow or red button next to the sub-contractor based on the provision the main contractor has chosen and their bank status, in addition to a risk assessment from the program. When there is a red button the main contractor often choose not to use the subcontractor.

\section{Challenges With The Requirement of MaXimum Two Contract TIERS}

The literature does not describe much about the negative effects or challenges that may arise with the introduction of two contract tiers in the vertical supply chain. The results in this study did not reveal large challenges that the main contractors and clients experienced but rather on the contrary. From the interviews it seemed like contractors did not struggle with being limited to two contract tiers on standard construction projects, and would rather acclaim the requirement for cleaning up a rather messy chain management issue.

Some were sceptical when the requirement was first introduces due to areas where it might appear that it depended on three links, such as ventilation. Nevertheless the 
experiences from the interviews is that they have managed to adapt and operate normally. Of course in some cases it has been necessary with three sub-contractors but it is then considered by the client and they can be granted a pass. The times the contractors has been challenged on the necessity of three links are special buildings and arrangements when a specialist must be appointed. In the cases where the extension of sub-contractors are needed due to specialists and not capacity is often a reason for acceptance.

As mentioned in the previous section there is still some challenges in securing the contract and seriousness requirements down the contract chain. Even though there are only two sub-contractors it is still difficult to ensure that the sub-contractor communicates the requirements to the next link. It is also argued that the overview for the main contractor is worse with the requirement because all the sub-contractors only move to the same horizontal line directly under the main contractor and therefor gives the main contractor more to follow-up on.

Why the main contractors and clients experience only a small amount of challenges with being limited to two contract tiers may be that the measure do not prevent the contractors from achieving their profit targets. The contractors are still able to fulfil their deliveries and achieve their goals just as efficiently and quality assured while the clients feel they have more control than before. In that way they don't experience anything negative and thus do not look for it either. Had the requirement of only using two contract tiers possibly prevented the contractors achieving their profit target, then the results would perhaps have been somewhat different.

Due to the Oslo model wanting to reduce the contract tiers even more, the question of challenges in this case were also included in the study (Oslo Municipality, n.d). There were relatively negative attitudes from the contractors regarding this. Previous research also indicates that the reduction only benefits the clients, in that they can experience a better sense of control (Stormo 2017). Possible effect of the reduction is argued to be that the main contractors themselves become more willingly to make clever agreement with the sub-contractors in order to gain a competitive advantage. This can quickly become a solution if the requirements becomes so strict that they are perceived to interfere with the contractors' performance goals. It is thus assumed that reducing the contract tiers again is an unnecessary measure as it possibly will create more problems than solutions for the contractors, in addition to not prevent more crime but rather provoke it.

The reasoning behind the argument for not reduce the contract tiers in the requirement can also bring light to the reason why nobody is experiencing challenges with the requirement today. It is indicated by advisors in the interviews that some contractors make clever arrangements when they can't handle only using two sub-contractors in their vertical supply chain. That means it is possible that someone is experiencing some difficulties with the requirement and won't tell because they are solving it illegally.

\section{CONCLUSION}

This study is established to explore experiences with the requirement of maximum two contract tiers from Norwegian contractors by answering the following research questions:

(1) How do contractors satisfy the requirement of maximum two contract tiers? and

(2) What challenges entails the requirement of maximum two contract tiers for the contractors?

The contractors satisfy the requirement of maximum two contract tiers with help from the data program HMSREG (HSE-registration). The program is a tool to maintain better control and overview. Maximum two contract tiers - entailing a shorter but wider supply 
chain - prevents work related crime. A shorter supply chain can prevent hidden crime from appearing down in the chain, where it can be challenging for the main contractor to uncover. The requirement itself is good, but it must be supplemented with other tools to be able to fill its purpose as a whole. It is not a waterproof measure against work related crime alone. HMSREG strengthened the measures taken and has potential to counteract work related crime in the future.

There are not many challenges entailing the requirement of maximum two contract tiers. The overall experiences with the requirement are positive. The main contractors experience control when using the requirement. The only challenge in this matter is when their sub-sub-contractor needs specialist competence or specialist equipment. However, there are still some communication difficulties with securing the contract and seriousness requirements down the contract chain between the main contractor and the sub-subcontractor, but it appears to not be worse than before. The contractors have a belief that the requirement is not limiting their work, but rather cleans up a long and messy vertical chain, which benefits them as a legal company. Possible reason for a small amount of challenges being revealed may be that the requirement does not limit their results. If the requirement prevented the contractors from achieving their profit goals, it would be reasonable to assume that the results would be different. However, the interviewees mentioned that the requirement could cause unintended consequences. For example, the main contractors can bypass the requirement by fabricating a contract with the sub-subcontractor, while the real contract relationship is between the sub-contractor and the subsub-contractor. Then business looks good from the outside, while it is not.

This study is limited to Norwegian contractors, and concentrates on the requirement of maximum two contract tiers. Further studies should explore experiences of international contractors, as well as the experiences of more clients and sub-contractors. Other measures set to counteract work related crime and their impact should also be explored.

\section{REFERENCES}

Arksey, H. and O'Malley, L. 2005. "Scoping studies: towards a methodological framework." International Journal of Social Research Methodology, 8:1, 19-32.

Ballard, G. and Howell, G. 1998. "What Kind of Production Is Construction?" In: Proc. 6th Annual Conference of the International Group for Lean Construction, Guarujá, Brazil, 13-15 Aug 1998.

Blumberg, B., Cooper, D. R. and Schindler, P. S. 2011. Buisness Research Methods. 3. europeiske utgave ed. Berkshire: McGraw-Hill Education.

Brandi, T. S., Fulgesang, M. and Rekkedal, K. A. 2017. Nye regler begrenser bruk av underleverandører [New rules restrict the use of subcontractors], s.l.: Selmer.

Broft, R. D. and Koskela, L. 2018, "Supply Chain Management in Construction From a Production Theory Perspective" In: Proc. 26th Annual Conference of the International Group for Lean Construction, Chennai, India, 18-20 Jul 2018. pp. 271281

Dalen, M. 2011. Intervju som forskningsmetode. [Interview as a research method] 2. utgave red. Oslo: Universitetsforlaget.

Engebø, A., Lohne, J., Rønn, P. E. and Lædre, O. 2016, "Counterfeit Materials in the Norwegian AEC-Industry" In: Proc. 24th Annual Conference of the International Group for Lean Construction. Boston, USA, 20-22 Jul 2016. pp 13-22. 
Evjen, S., Gunnerud, G., Lædre, O. Søfting, R. and Lohne, J. 2019, "Sub-Contractors' Perception of Contracting: The Case of Crime" Lill, I. and Witt, E. (Ed.) $10^{\text {th }}$ Nordic Conference on Construction Economics and Organization (Emerald Research Proceedings Series, Volume 2, Emerald Publishing Limited, pp. 59-67.

Fellesforbundet, 2014. Skiens modellen, [The Norwegian United Federation of Trade Unions, The Skien model] < https://www.fellesforbundet.no/avdelinger/avd008/skienog-telemarks-modellen/skiens-modellen/ > (Oct 2019)

Gulliksen, R.-S., Rognes, K., Gransmo, M. D., Saksæther, B., Hestenes, E., Torgersen, C., Flekke, A., Bustø, M., Slettemoen, A. I. 2014. Arbeidsmarkedskriminalitet i Norge - Situasjonsbeskrivelse. [Work related crime in Norway, Situational] $<$ https://www.politiet.no/globalassets/04-aktuelt-tall-ogfakta/arbeidslivskriminalitet/arbeidsmarkedskriminalitet-i-norge---tverretatligsituasjonsbeskrivelse-2014.pdf $>($ Oct 2019)

Haelterman, H. 2009. "Situational Crime Prevention and Supply Chain Security: An "Ex Ante" Consideration of Preventive Measures", Journal of Applied Security Research, 4:4, 483-500.

Hardoon, D. and Heinrich, F. 2011. Bribe Payers Index, s.1.: Transparency International. Haugen, A., Wondimu, P. A., Lohne, J. and Lædre, O. 2017. "Project delivery methods in large public road projects - a case study of E6 Jaktøyen - Sentervegen." Procedia Engineering, Volume 196, pp. 391-398.

Johansen, R. and Steen, R. 2017. Byrådssak 1057/17, Oslo: Oslo Municipality, Byrådsavdeling for finans, [City Council Departement of Finance].

Karim, K., Marosszeky, M. and Davis, S. 2006. "Managing subcontractors supply chain for quality in construction.", Sydney: Emerald Group Publishing Limited.

Kjesbu, N. E., Engebø, A., Lædre, O. and Lohne, J. 2017, "Counterfeit, Fraudulent and Sub-Standard Materials: The Case of Steel in Norway" In: Proc. 25th Annual Conference of the International Group for Lean Construction (IGLC). Heraklion, Greece, 9-12 Jul 2017, pp 805-812.

Locatelli, G., Mariani, G., Sainati, T. and Greco, M. 2016. "Corruption in public projects and megaprojects: There is an elephant in the room!" Elsevier Ltd: International Journal of Project Management, Volume 35, Issue 3, April 2017, pp. 252-268.

Lohne, J., Kjesbu, N. E., Engebø, A. and Young, B. 2019a. "Scoping Literature Review of Crime in the AEC Industry." Journal of Construction Engineering and Management, Volume 145, Issue 6.

Lohne, J., Engebø, A. and Lædre, O. 2020. "Ethical challanges during construction project handovers." International Journal of Project Organisation and Management, 12(1) s.31-53.

Lohne, J., Drevland, F. and Lædre, O. 2019b. "Who Benefits From Crime in Construction? A structural Analysis", Gøteborg: Emerald Publishing Limited.

Mays, N. B., Roberts, E. and Popay, J. 2001. Synthesising research evidence, London: Routledge: In Studying the organization and delivery of health services: Research methods.

Neby, S., Nesheim, T., Ryssevik, J., Rubecksen, K., Dahle, M., Nordhagen, I. 2016. Innsats mot arbeidslivskriminalitet, [Effort to combat work related crime] Bergen: Uni Research.

Oslo Municipality, n.d. Oslomodellen. < https://www.oslo.kommune.no/politikk-ogadministrasjon/for-vare-leverandorer/oslomodellen/\#gref > (01 10 2019) 
Skovly, M. Mørenskog, A.R., Engebø, A., Lædre, O., Lohne, J. 2017, "Measures to counteract work-related crime - airport developments in Norway." Procedia Computer Science, 121, pp. 664-671.

Souza, D. V. S. and Koskela, L. 2013, "Practices for Designing and Improving Construction Supply Chain Management" In: Formoso, C. T. and Tzortzopoulos, P., Proc. 21th Annual Conference of the International Group for Lean Construction. Fortaleza, Brazil, 31-2 Aug 2013. pp 155-164.

Souza, D. V. S. and Koskela, L. 2014, "Interfaces, Flows, and Problems of Construction Supply Chains - A Case Study in Brazil” In: Kalsaas, B. T., Koskela, L. and Saurin, T. A., Proc. 22nd Annual Conference of the International Group for Lean Construction. Oslo, Norway, 25-27 Jun 2014. pp. 1095-1106.

Stormo, J. K. 2017. Innføring av maksimalt to ledd av underentreprenører $i$ Statens vegvesens prosjekter, [Introduction of a maximum two contract tiers in the Norwegian Public Road Administration's projects] Trondheim: NTNU.

Svalestuen, F., Lohne, J., Knotten, V., and Lædre, O. 2015, "Ethics of the Design Phase - a Descriptive Approach" In: Seppänen, O., González, V. A. and Arroyo, P., Proc. 23rd Annual Conference of the International Group for Lean Construction. Perth, Australia, 29-31 Jul 2015. pp 609-618

Tjora, A. H. 2017. Kvalitative forskningsmetoder i praksis, [Qualitative research methods in practice] 3.utg red. Oslo: Gyldendal akademisk.

Wold, J., Lædre, O. and Lohne, J. 2019, "Questionable Practice in the Processing of Building Permits in Norway" In: Pasquire C. and Hamzeh F.R. (ed.), Proc. 27th Annual Conference of the International Group for Lean Construction, Dublin, Ireland, pp. 1151-1162. 
Experiences from Allowing Maximum Two Contract Tiers in the Vertical Supply Chain

This page was intentionally left blank. 